\title{
Processing of TCP pilin by TcpJ typifies a common step intrinsic to a newly recognized pathway of extracellular protein secretion by gram-negative bacteria
}

\author{
Melissa R. Kaufman, ${ }^{1}$ Jerome M. Seyer, ${ }^{2}$ and Ronald K. Taylor ${ }^{1}$ \\ ${ }^{1}$ Department of Microbiology and Immunology, and ${ }^{2}$ Biochemistry, University of Tennessee at Memphis, \\ Memphis, Tennessee 38163 USA
}

\begin{abstract}
Biogenesis of the Vibrio cholerae toxin-coregulated pilus (TCP) requires the activities of at least seven accessory proteins. We demonstrate that a portion of this pathway involves a novel processing step in which a hydrophilic leader peptide is proteolytically removed from TcpA by the gene product characterized in this report, TcpJ, to yield the mature, export-competent form of the pilin. Cleavage of the pilin leader peptide is independent of known signal peptidases as demonstrated by pilin-processing profiles in Escherichia coli strains conditionally defective for production of leader peptidase or grown in the presence of the antibiotic globomycin. Additionally, pilin cleavage did not rely on the SecA protein, as evidenced by TcpA processing in azide-treated cells. These results suggest that $T c p J$ is representative of a new class of proteins involved in SecA-independent proteolytic cleavage of a set of atypical leader peptides during extracellular export.
\end{abstract}

[Key Words: Protein secretion; Vibrio cholerae; TCP; pilus biogenesis; tcpI]

Received June 19, 1991; revised version accepted August 12, 1991.

Extracellular secretion of proteins composing macromolecular complexes on the bacterial cell surface occurs by a mechanism poorly defined in comparison to the initial stages of classic prokaryotic protein export (for recent review, see Bieker et al. 1990). The pathway for biogenesis of the toxin-coregulated pilus (TCP) of Vibrio cholerae provides a model system to study such secretion processes. TCP is a cell-surface, filamentous organelle likely to be a homopolymer of pilin subunits encoded by tcpA (Sun et al. 1990). Amino acid sequencing of gelpurified TcpA reveals an amino-terminal region that bears striking homology to the type 4 pilins utilized by a variety of pathogenic bacteria for adherence and colonization (Taylor et al. 1987). A large hydrophobic domain is created by the first 25 residues of mature TcpA and is likewise present in all type 4 pilins. For PilA of Pseudomonas aeruginosa, and probably all type 4 pilins, this internal hydrophobic stretch is essential for pilin membrane translocation (Strom and Lory 1987). Preceding this hydrophobic region is a highly charged, basic "leader peptide" that differs significantly from the typical proteolytically cleaved leader sequences found on most exported proteins (von Heijne 1986).

Previously characterized pilus systems in Escherichia coli reveal that numerous gene products, often located adjacent to the major subunit, are instrumental for pilus formation and function (for recent review, see Tennent et al. 1990). Primary evidence that linked genes were involved in TCP formation came from studies in which $V$. cholerae cosmid clones in $E$. coli were screened for TcpA expression by Western blot analysis. Two classes of cosmid clones were identified: those that expressed TcpA in the expected $20.5-\mathrm{kD}$ form, and those that synthesized a $23-\mathrm{kD}$ cross-reactive protein thought to be a pilin precursor, suggesting the presence of linked genes encoding products required for TcpA maturation (Shaw and Taylor 1990). Deletion mapping and TnphoA mutagenesis of these cosmids determined that secretion of the TCP pilin subunit and organelle biogenesis require the products of at least seven genes located adjacent to $t c p A$ (Taylor et al. 1988). The region downstream of $t c p A$ necessary for conversion of pilin to its mature $20.5-\mathrm{kD}$ form was localized to a $3.3-\mathrm{kb} H$ indIII-EcoRV restriction fragment present on pCS19H (Shaw 1988). In this investigation we demonstrate that creation of the $20.5-\mathrm{kD}$ pilin involves the proteolytic cleavage of an unusual leader peptide mediated by the product of the $t c p I$ gene. Furthermore, we report that this processing of TcpA is in- 
dependent of the major signal peptidases of $E$. coli and does not rely on the well-characterized secretory apparatus component SecA.

\section{Results}

\section{Pulse-chase analysis}

To evaluate the role that accessory protein(s) may have in creating the differentially migrating forms of TcpA it was necessary to determine whether the two pilin species recognized previously in Western blots actually represented proteolytic processing of a larger precursor form. One piece of evidence that implies a proteolytic cleavage of TcpA emerges from the DNA sequence /Faast et al. 1989; Shaw and Taylor 1990). The predicted size of the TcpA leader peptide correlates directly to the $2.5-\mathrm{kD}$ difference between the two forms of TcpA visualized in Western blots. Pulse-chase experiments (Fig. 1) were used to follow conversion of prepilin to pilin as described in Materials and methods. As we have been unable to immunoprecipitate TcpA, the in vivo bacteriophage T7 RNA polymerase/promoter system (Tabor and Richardson 1985) was employed to selectively express TcpA for pulse-chase analysis. In the presence of TcpI, labeled TcpA chased to the $20.5-\mathrm{kD}$ form in a time-dependent manner (lanes 4-9). By 60 minutes, the majority of TcpA was found at its mature molecular mass (lane 9). This behavior suggests that the $20.5-\mathrm{kD}$ protein is likely to represent a processed or modified form of prepilin.

\section{Amino acid sequencing of precursor TcpA}

To eliminate the possibility of modification solely influencing the migration of TcpA, the amino terminus of the 23-kD precursor form was sequenced. Construct $\mathrm{p} 3 \mathrm{Z}-\mathrm{A}$ was used to overproduce $23-\mathrm{kD}$ prepilin that was electrophoresed by SDS-PAGE and transferred to PVDF membrane as described in Materials and methods. The 32 amino acid residues resolved by microsequencing match those predicted by the DNA sequence and overlap the amino-terminal amino acids previously determined (Fig. 2). This sequence correlated exactly with the $2.5-\mathrm{kD}$ migration difference and, in conjunction with the pulse-

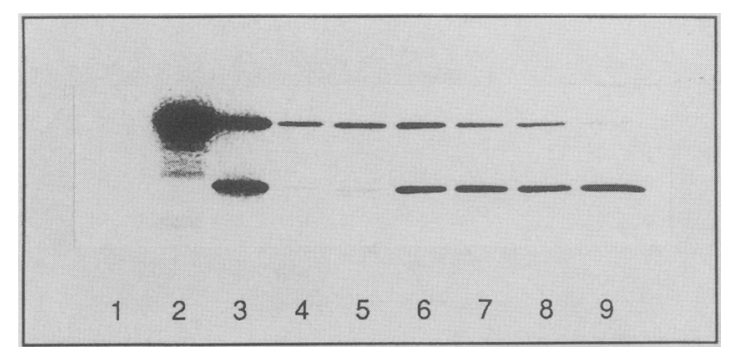

Figure 1. Pulse-chase analysis of TcpA maturation in E. coli. (Lane 1) K38 pGP1-2 pGEM-3Z; (lane 2) K38 pGP1-2 p3Z-A; (lane 3) K38 pGP1-2 pRIN2A.7, showing the processing profile at steady-state. Remaining lanes contain K38 pGP1-2 pRIN2A.7 labeled with $\left[{ }^{35} \mathrm{~S}\right] \mathrm{methionine}$ for $2 \mathrm{~min}$ and chased with an excess of cold methionine for $0 \mathrm{~min}$ (lane 4), $1 \mathrm{~min}$ (lane 5), $5 \mathrm{~min}$ (lane 6), $15 \mathrm{~min}$ (lane 7), $30 \mathrm{~min}$ (lane 8), and $60 \mathrm{~min}$ (lane 9). chase analysis, determined that mature $20.5-\mathrm{kD}$ pilin arose from a proteolytic cleavage of the $23-\mathrm{kD}$ precursor form of TcpA between residues Gly $(-1)$ and $M e t(+1)$.

\section{Modification of TcpA}

The original sequencing of the amino terminus of mature TcpA revealed a modified amino-terminal residue, which was thought to likely be an $N$-methylphenylalanine by analogy to previously characterized type 4 pilins (Taylor et al. 1987). Since then, the DNA sequence and the amino acid sequence of precursor TcpA (Fig. 2) place a methionine at the +1 position. It was therefore of interest to determine the nature of the modification of the amino-terminal residue. The chromatographic behavior of the modified residue was compared to a panel of commercially available methionine derivatives and a monomethylated tripeptide, as described in Materials and methods. Mature pilin contained a modified methionine that cochromatographed with $\mathrm{N}$-monomethylmethionine.

\section{Nucleotide sequence of tcp I and properties} of the deduced protein sequence

The dideoxy chain-termination method of Sanger et al. (1977) was employed to determine the DNA sequence of a 980-bp EcoRI-NsiI fragment present on plasmid pRIN980 which, on the basis of deletion analysis, is the smallest clone that still encodes the TcpA processing activity. Appropriate restriction fragments were introduced into M13 phage vectors (Kieny et al. 1983; Messing 1983) for single-stranded sequencing, or doublestranded molecules were directly sequenced from plasmid clones with a modification of the protocol of Birnboim (1983) for template preparation. The sequence revealed an open reading frame within the 980-bp EcoRINsiI restriction fragment that would encode a 253-residue protein corresponding to the $t c p /$ gene product (Fig. 3). Placement of a 1.1-kb kanamycin-resistance cartridge from pUC71K (Ruther 1980) into the unique SnaBI site in $t c p /$ eliminated TcpA processing activity completely in E. coli (Fig. 5, IIA), suggesting further that this reading frame contained the pilin-processing activity. A Kyte and Doolittle (1982) hydropathicity profile of TcpJ intimates that the protein is dominated by large hydrophobic domains interrupted by short, charged stretches. This striking hydrophobicity may be indicative of membrane localization. To reveal any homologies between known proteins and TcpI, the TFASTA program of Lippman and Pearson (1985) was employed. An alignment of TcpJ and the highest-scoring proteins found in the data base is shown in Figure 4. The most significant homology occurred with a pilus biogenesis protein from $P$. aeruginosa, PilD (Nunn et al. 1990), which has endopeptidase activity in vitro (Nunn and Lory 1991). Additional molecules involved in translocation processes, namely PulO of Klebsiella pneumoniae (Pugsley and Reyss 1990) and ComC of Bacillus subtilis (Mohan et al. 1989), also shared extensive homology with TcpJ. The boxed cysteine residues represent conserved regions that are pos- 


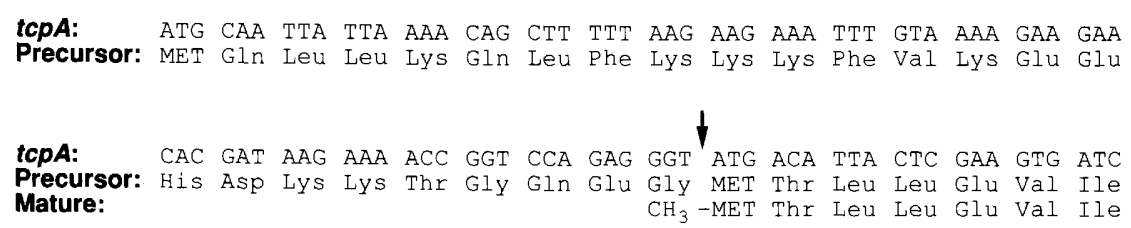

Figure 2. Amino-terminal sequence and modification of TcpA. The first 32 residues of $23-\mathrm{kD}$ TcpA correspond to those predicted by DNA sequence analysis and overlap previously determined residues from mature pilin (Taylor et al. 1988). The site of proteolytic cleavage of prepilin is indicated by a vertical arrow. Included on the mature protein is an $N$-methylation of the methionine residue.

sibly essential for in vitro peptidase activity in $P$. aeruginosa (Nunn and Lory 1991). Interestingly, these cysteine motifs also resemble the metal-binding domains of the zinc finger consensus (Berg 1990), which might suggest a metal ion requirement for activity.

\section{V. cholerae tcpl mutant}

To analyze TcpJ function, it was crucial to define the phenotype of a $V$. cholerae strain defective for produc- tion of TcpJ. To create an isogenic strain of $V$. cholerae O395 unable to express wild-type TcpJ, a marker exchange technique that exploits plasmid incompatibilities was utilized to select recombinant strains as outlined in Materials and methods. Replacement of the wild-type locus with the $t c p /$ insertion by homologous recombination between flanking sequences was confirmed by Southern blot analysis (Southern 1975), by utilizing a 2.4-kb BglII fragment as a probe (Fig. 5). Figure 5(IA) shows the hybridization pattern of control plas-
Figure 3. Nucleotide sequence of $980-$ bp EcoRINsiI fragment containing tcpJ. The deduced amino acid sequence indicates an open reading frame for TcpJ of 253 residues. Amino acid residues are numbered at left. A putative ribosomebinding site is shown in boldface type (Shine and Dalgarno 1974). The GenBank accession number for the tcpI DNA sequence described above is M74708.
50

GAATTCAAAATAAAACAGATTGCATATCAGTCTGGGTTTGCTAGCGTTTCATATTTTTCTACAGTATTTAA 100

GTCAACCATGAATGTAGCACCAAGTGAATATTTATTTATGTTGACAgGagtTGCAGAAAAATA ATG GAA 150

TAC GTT TAC TTG ATC CTA TTT TCG ATT GTA TCA CTG ATT TTG GGT AGT TTT AGT

3 Tyr Val Tyr Leu Ile Leu phe Ser Ile Val Ser Leu Ile Leu Gly Ser phe Ser 200

AAT GTT GTG ATT TAT CGT CTA CCA AGA AAA ATT TTA CTA AAG AAT CAT TTT TTT

21 Asn Val Val Ile Tyr Arg Leu Pro Arg lys Ile Leu Leu Lys Asn His phe phe 250

TAT GAC ATC GAT TCA AAT CGT TCC ATG TGC CCT AAA TGT GGA AAT AAA ATC AGT

39 Tyr Asp Ile Asp Ser Asn Arg Ser Met Cys Pro Lys Cys Gly Asn Lys Ile Ser 350

TGG TAT GAT AAT GTT CCA TTG TTA AGT TAT TTG TTA CTT CAT GGT AAG TGT AGA

57 Trp Tyr Asp Asn Val pro Leu Leu Ser Tyr Leu Leu Leu His Gly Lys Cys Arg 400

CAT TGT GAT GAA AAA ATT TCA TTA AGT TAT TTT ATT GTC GAG TTA TCA TTT TTT

75 His Cys Asp Glu Lys Ile Ser Leu Ser Tyr Phe Ile Val Glu Leu Ser Phe Phe 450

Ata ATC gCA tTt CCA Ata tat tgg tTa tCA ACt GAC TGg gTt gat tCg tTC gta

93 Ile Ile Ala Phe Pro Ile Tyr Trp Leu Ser Thr Asp Trp Val Asp Ser Phe Val 500

TTG CTC GGG CTT TAC TTT ATT TTA TTC AAT CTT TTT GTA ATT GAT TTT AAA TCT

111 Leu Leu Gly Leu Tyr phe Ile Leu phe Asn Leu phe Val Ile Asp phe Lys Ser 550

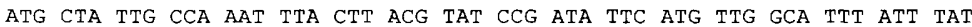

129 Met Leu Leu pro Asn Leu Leu Thr Tyr Pro Ile phe Met Leu Ala Phe Ile Tyr 600

GTG CAG CCA AAT CAA GCA TTA ACA GTT GAA AGC TCT ATT ATT GGT GGT TTT GCG

47 Val'Gln Gln Asn Pro Ala Leu Thr Val Glu Ser Ser Ile Ile Gly Gly Phe Ala 650

GCT TTC ATC ATT ACC TAT GTG AGT AAT TTC ATT GTT CGG TTA TTC AAA AGA ATC

165 Ala Phe Ile Ile Thr Tyr Val Ser Asn phe Ile Val Arg Leu phe Lys Arg Ile 700

GAT GTG ATG GGA GGT GGA GAT AtA AAG CTC TAT ACt GCG ATT GGT ACT CTT ATC

183 Asp Val Met Gly Gly Gly Asp Ile Lys Leu Tyr Thr Ala Ile Gly Thr Leu Ile 750

GGT GTT GAG TTT GTA CCA TAT TTA TTC TTG CTG TCC TCG ATT ATT GCA TTT ATT

201 Gly Val Glu phe Val pro Tyr Leu Phe Leu Leu Ser Ser Ile Ile Ala Phe Ile 800

CAT TGG TTT TTT GCT AGA GTC TCA TGT CGG TAT TGC TTA TAT ATC CCT CTT GGA

219 His Trp phe phe Ala Arg Val Ser Cys Arg Tyr Cys Leu Tyr Ile Pro Leu Gly 850

CCA AGC ATT ATT ATC TCT TTT GTA ATT GTT TTT TTT TCA ATC CGT TTA ATG TGA

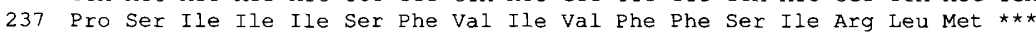
900 950

GCTAAAATGAAGTTTTCTATCAAGTTACTAATGATTTTTACATCAATTATAATTACTATTTCATCTATCCT 


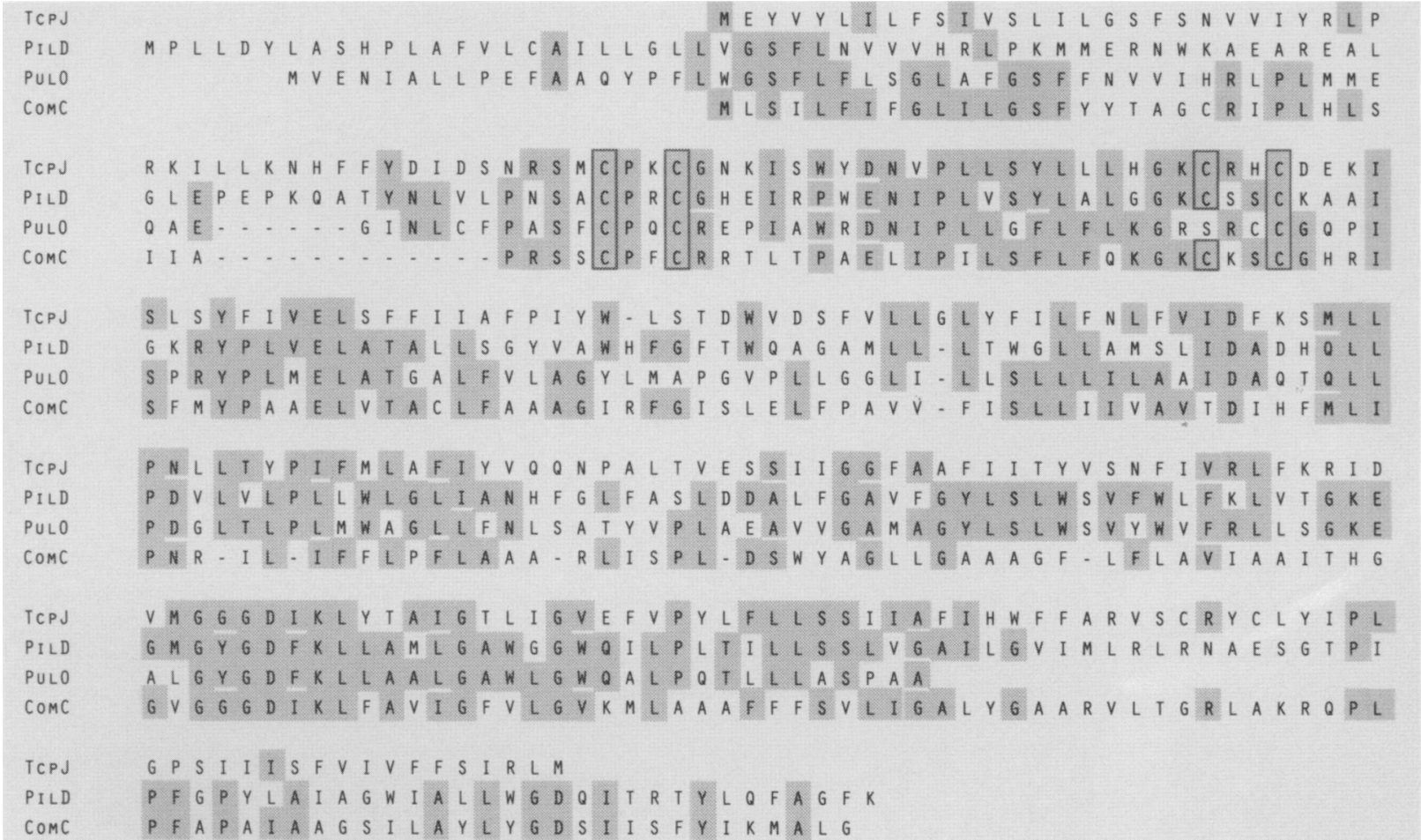

Figure 4. Alignment of TcpJ, PilD, ComC, and PulO. Sequences from the GenBank-EMBL data base of PilD, ComC, and PulO are compared to those of TcpJ. Amino acids are given in single-letter code, and gaps have been added to improve the alignment. Shaded regions indicate identical residues; conserved cysteine motifs are boxed.

mids p325-J and p325-J71K, encoding tcpl and the $k a n^{\mathrm{r}}$ insertion, respectively. Radiolabeled probe annealed to a 2.4-kb BglII fragment in the unmutagenized construct, which increases to a $3.5-\mathrm{kb} B g I I I$ fragment when $t c p I$ carries the $1.1-\mathrm{kb}$ insertion. Corresponding patterns were observed with $V$. cholerae $\mathrm{O} 395$ and two isolates of the $t c p I: \because \mathrm{kan}^{\mathrm{r}}$ chromosomal integration (Fig. 5, IB). Immunoblots to assay the extent of removal of TcpA leader peptide were performed on one of the isolates, J71K-1, revealing a significant processing defect as compared to wild type (Fig. 5, IIB). The gel stained with Coomassie brilliant blue shown in Figure 5 (III) was used for densitometric scanning demonstrating $80 \%$ of TcpA remained in its $23-\mathrm{kD}$ precursor form in the $t c p /$ mutant strain. Even though a portion of pilin appears in the mature form, the mutants failed to autoagglutinate, a property conferred by wild-type expression of TCP. In addition, there was no detectable surface expression or secretion of assembled pili as evaluated by electron microscopy (Fig. 6B).

\section{Complementation of tcpJ mutation}

To confirm that the TcpA processing defect observed in $V$. cholerae $\mathrm{J} 71 \mathrm{~K}-1$ was a direct result of the insertion mutation disrupting expression of $t c p I$ as opposed to a polar effect on downstream genes that could also be required for pilin processing, we complemented the $t c p I$ mutant in trans with a plasmid carrying $t c p /$ alone. Plasmid pRIN980, containing the 980 -bp clone of $t c p /$, was transformed into $771 \mathrm{~K}-1$ as described in Materials and methods. When the resulting strain J71K-1 pRIN980 was grown under conditions optimal for TCP expression (LB at $\mathrm{pH} 6.5$ and $30^{\circ} \mathrm{C}$ ), autoagglutination activity was restored and the majority of prepilin was processed effectively as determined by Western blot analysis (Fig. 5, IIB). Pili that were morphologically indistinguishable from wild type were again visible by electron microscopy (Fig. 6C).

\section{Localization of TcpA in wild-type} and tcpJ mutant strains

Thin sections of bacteria, embedded into stable resins and stained or immunolabeled, are often employed to study cellular ultrastructure and antigen localization (Bayer et al. 1987; Durrenberger et al. 1988). Immunolabeling of thin sections of cryosubstituted, Lowicryl-embedded $V$. cholerae with TcpA antisera and protein A-collodial gold was used to determine TcpA localization in wild-type and $t c p /$ mutant strains to gain insight into the pathway utilized for processing and secretion (Fig. 7). Preimmune controls showed a low level of sporadic labeling indicative of nonspecific interactions (Fig. 7A). Control antibodies directed against DNA exclusively labeled the cytoplasmic space (Fig. 7B; Marion et 
Figure 5. Insertion mutagenesis of $t c p /$. Strategy for creation of the insertion lesion is outlined in the text and diagram at top. Abbreviations: $(\mathrm{H})$ HindIII; $(\mathrm{Bg}) \mathrm{BgIII}$; $(\mathrm{X})$ XhoI; (E) EcoRI; (C) ClaI; (Sn) SnaBI; (Ns) NsiI; (Bc) BclI; (RV) EcoRV. (I) Southern blot analysis with $2.4-\mathrm{kb} B g I I I$ probe. $|A|$ (Lane 1) Plasmid p325-J digested with BglII; (lane 2) plasmid p325-J71K restricted with BgIII. Hybridization patterns show the $1.1-\mathrm{kb}$ upshift in the mutated gene corresponding to the insertion. $(B)$ (Lane 1) $V$. cholerae O395 chromosomal DNA digested with BgIII; (lane 2) recombined mutant strain $771 \mathrm{~K}-1$ chromosomal prep restricted with BglII. The BglII fragment containing $t c p /$ and the kanamycin resistance cartridge is $1.1 \mathrm{~kb}$ larger in this mutant strain. (II) Immunoblot analysis. Blots were probed with a $1: 1000$ dilution of anti-TcpA antisera. (A) (Lane 1) SE5000 p325-J pDra9; (lane 2) SE5000 p325-J71 K pDra9 demonstrating an elimination of processing activity in E. coli. (B) (Lane 1) V. cholerae O395; (lane 2) V. cholerae J71K-1 showing a significant processing defect in the mutant as compared to wild type; (lane 3) J71K-1 pRIN980 complements the reduction of TcpA processing in the $t c p /$ insertion mutant by supplying tcp/ in trans. (III) Quantitation of the TcpA-processing defect was determined by densitometric scanning of this polyacrylamide gel stained with Coomassie brilliant blue. (C) (Lane 1) O395; (lane 2) J71K-1 shows $80 \%$ of pilin in the $23-\mathrm{kD}$ precursor form.

al. 1982). Labeling of assembled pili bundles was demonstrated in wild-type $V$. cholerae probed with antiTcpA antisera (Fig. 7C). Cell-associated pilin in wildtype bacteria was distributed approximately equally between the inner or outer membranes (Fig. 7D). Cellular fractionations also indicated that pilin was almost exclusively membrane-localized (J. Peek and R. Taylor, in prep.). Mutants containing an insertion in $t c p /$ retained a higher percentage of pilin in the cytoplasm and lacked assembled or exported pilin (Fig. 7E,F). Most pilin remained membrane-associated, suggesting that export was blocked at this step in the mutant.

\section{TcpA processing in a leader peptidase mutant}

To determine whether TcpJ activity is independent of known peptidases that function in the processing of secreted proteins, we took advantage of a conditional lethal point mutation in $E$. coli of the leader peptidase gene (lep) constructed by Inada et al. (1989). As demonstrated in Figure 8, in the absence of a functional leader peptidase, $\beta$-lactamase remained in its precursor form (lane 4). However, TcpJ-dependent cleavage of pilin leader peptide was unaffected at the nonpermissive temperature (lane 8). The continuation of TcpA processing without leader peptidase suggests a novel secretory pathway involving the $t c p /$ gene product functions during pilus biogenesis in $V$. cholerae.

\section{TcpA processing in the presence of globomycin}

E. coli encodes a second leader peptidase for processing of glyceride-modified lipoprotein precursors (Yamada et al. 1984). To exclude use of lipoprotein-specific leader peptidase in TcpA processing, a T7 assay was performed in the presence of the antibiotic globomycin, a potent inhibitor of the lipoprotein peptidase (Hussain et al. 1980). As shown in Figure 9, TcpJ-dependent pilin processing was unaffected by incubation with $40 \mu \mathrm{g} / \mathrm{ml}$ of globomycin under conditions that inhibited the processing of a cloned $V$. cholerae lipoprotein, TcpC (Parsot et al. 1990). Hence, TcpA processing is independent of the known $E$. coli leader peptidases.

\section{TcpA processing profile in a lamB-lacZ fusion strain}

We speculate that TcpA, by virtue of its unusual leader sequence, membrane-bound translocation, and independence from leader peptidases I and II, may use an unconventional pathway for secretion. Gene-fusion technology has been used extensively to study protein secretion in prokaryotic systems (for recent review, see Schatz and Beckwith 1990). For example, E. coli strains carrying a lamB-lacZ gene fusion exhibit a pleiotropic defect in export and accumulate secretory protein precursors when high-level synthesis of the hybrid protein $(\lambda$ receptor : $\beta$-galactosidase) is induced by growth in maltose (Emr and Silhavy 1980). Overproduction of the fusion protein is lethal because of a jamming of the secretion apparatus, resulting in accumulation of secretory protein precursors in the cytoplasm, and is known to specifically sequester at least one component of the translocator, PrlA (SecY) (Bieker and Silhavy 1989). To investigate any dependence on the classical apparatus for TcpJ-mediated processing of TcpA, we performed a T7 analysis in $E$. coli strains DK2179 (IamB-lacZ 42-1) and an isogenic strain with a $\operatorname{lam} B$ signal sequence mutation that relieves the overproduction lethality BZR60 (IamBA60-lacZ 42-1). 


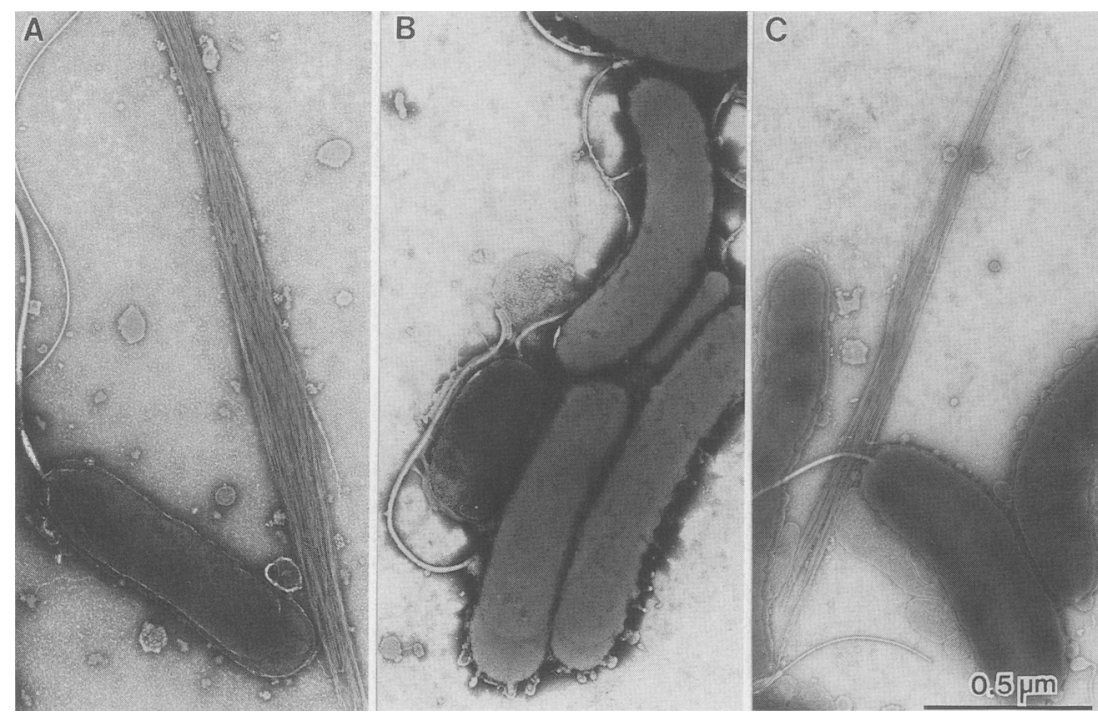

Figure 6. Complementation of $V$. cholerae tcp I mutant. Organisms were grown under conditions favoring TCP expression and negative-stained as described in Materials and methods. (A) Wild-type $V$. cholerae strain 0395 showing characteristic TCP bundles in the extracellular space; $(B)$ J71K-1 tcpI insertion mutant fails to produce pili able to assemble bundles; $(C)$ J71K-1 pRIN980 demonstrating that providing $t c p /$ in trans complements the pilus assembly defect in the $t c p /$ mutant.

Because overproduction of $\beta$-lactamase compromised the ability of the cells to process the molecule efficiently, we performed a modified assay in which the basal level synthesis of T7 RNA polymerase was sufficient to transcribe from the $\mathrm{T} 7$ promoter without induction at $42^{\circ} \mathrm{C}$. After growth in maltose minimal media for 1,2 , or $3 \mathrm{hr}$, rifampicin was added and cells were incubated for $30 \mathrm{~min}$ prior to labeling (Fig. 10). During the time course, the DK2179 strains showed a gradual decrease in the amount of TcpA processing as the fusion protein accumulated in the cells (lanes $4,8,12$ ). No such effect was observed for the BZR60 strains. This lack of processing in the cells expressing high levels of fusion protein suggests that either TcpA relies on components of the general export machinery or that the state of the membrane is such that proper localization and/or conformation of TcpJ is inhibited.

\section{TcpA processing in the presence of sodium azide}

Because of the block in leader peptide removal resulting from jamming the secretory apparatus with the LamBLacZ fusion protein, we investigated the possibility that processing of TcpA relied on a central component of the classical secretory apparatus in E. coli, SecA. SecA is a $102-\mathrm{kD}$ peripheral membrane protein essential for secretion of the majority of proteins localized beyond the cytoplasmic space in E. coli (Oliver and Beckwith 1982). The function of SecA in translocation is dependent on the ATPase activity of the molecule (Cabelli et al. 1988; Lill et al. 1989). Low levels of sodium azide ( $2 \mathrm{~mm}$ ) specifically inhibit export by poisoning the required ATPase activity of SecA /Schatz and Beckwith 1990; Senior 1990). As shown in Figure 11, functional inactivation of SecA by azide treatment rendered the molecule unable to translocate $\beta$-lactamase, as evidenced by its gradual precursor accumulation between 8 and $17 \mathrm{~min}$ of incubation with azide (lanes 2,3). However, leader sequence removal from TcpA remains unaltered between the 8and 17-min time points (lanes 8 and 9), suggesting that pilin processing occurs by a SecA-independent pathway.

\section{Discussion}

$V$. cholerae TCP pilus biogenesis requires the products of at least seven genes that are located adjacent to the pilin subunit gene $t c p A$ on the chromosome. In this study we addressed an initial step in pilus formation, that of the processing of precursor TcpA pilin into its mature, export competent form. This processing is of interest because precursor TcpA does not contain the typical signal sequence common to most exported proteins and is not processed in E. coli (Shaw and Taylor 1990). Instead, precursor TcpA possesses a hydrophilic amino-terminal protein domain that appears to be common to a certain class of pilins and some proteins involved with extracellular export from gram-negative bacteria (Nunn and Lory 1991). Processing of this leader is accomplished in $E$. coli when one of the adjacent $V$. cholerae pilus biogenesis genes, $t c p I$, is supplied in trans.

Pulse-chase analysis and amino acid sequencing confirmed that the two forms of TcpA identified previously (Shaw and Taylor 1990) did represent the processing of a precursor prepilin to the mature pilin form as proposed originally. Sequence of mature pilin from $V$. cholerae identified the amino-terminal modified amino acid residue as an $N$-methylmethionine. The presence of the methyl group sheds light on the mechanism of pilin processing because the major donor of methyl groups in bacteria is $S$-adenosylmethionine, a cytoplasmic constituent. Thus, the modification is likely to take place in the cytoplasm of the cell.

The 253-residue deduced primary structure of $t c p /$ reveals an extremely hydrophobic protein that is likely to span the cytoplasmic membrane, by analogy to the recently localized, highly homologous PilD protein of $P$. 
Figure 7. TcpA localization in Lowicryl thin sections. (A) V. cholerae 0395 incubated with preimmune sera to determine basal level of background labeling; $(B)$ O395 probed with DNA-specific monoclonal antibodies; $(C) \mathrm{O} 395$ incubated with antiserum raised against $\mathrm{Tcp} A$ elucidates bundles of pili in the extracellular space; (D) 0395 demonstrating the cellular distribution of TcpA in the wild-type organism; $(E, F) \mathrm{J} 71 \mathrm{~K}-1$ probed with TcpA-specific antisera shows that pattern of cellular TcpA localization in this mutant does not differ significantly from the wild type with respect to membrane distribution; however, a larger percentage of pilin remains cytoplasmically localized in the absence of functional TcpJ.

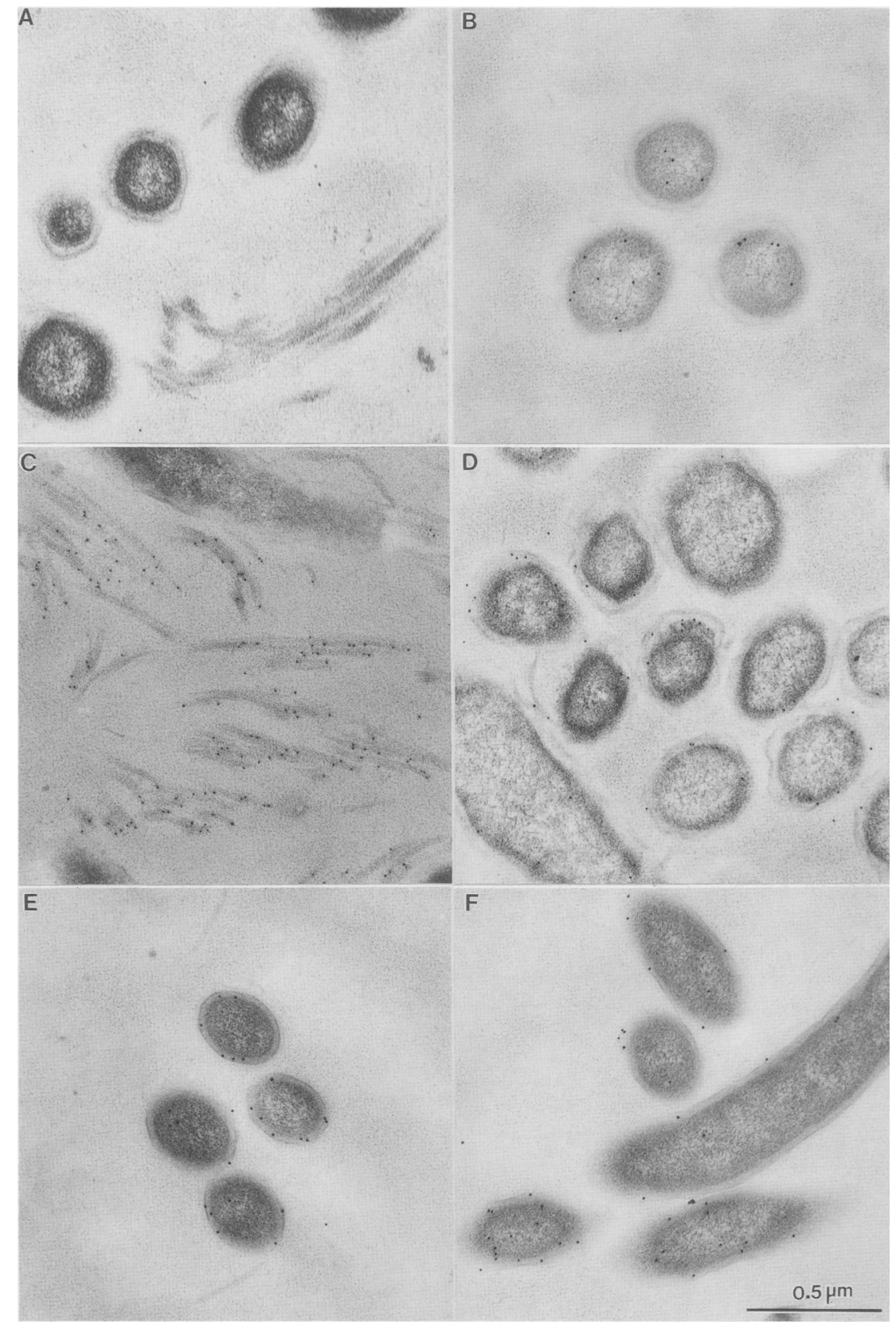

aeruginosa (Nunn and Lory 1991). A V. cholerae mutant of $t c p /$ constructed in this study shows a significant pilin-processing defect, fails to produce assembled pili, and can be complemented in trans by plasmid-encoded TcpJ. The residual pilin processing observed in the $t c p /$ mutant strain may be the result of a partially active truncated TcpJ molecule, nonspecific proteolytic activity, or an as yet unidentified TcpJ homolog. Unlike a $P$. aeruginosa mutant in pilD, the tcpI mutation does not confer a pleiotropic secretory defect as determined by examining toxin secretion in tcpJ mutant strains (data not shown). The overall pattern of cell-associated pilin during secretion in the $t c p /$ mutant does not appear to be dramati- cally different from the membrane-bound translocation of TcpA observed in the wild-type strain, with the exception of some cytoplasmic pilin accumulation. It was of interest to investigate further whether TcpJ catalyzes pilin processing by itself or whether it plays a role more in orienting prepilin for processing. To examine these possibilities, we evaluated the ability of TcpJ to catalyze pilin processing in the absence of known peptidases demonstrated previously to process secreted proteins. A T7 analysis with the $l e p^{\text {ts }}$ mutant strain IT41 demonstrated complete independence of pilin processing from the Lep protein. Inhibition of the signal peptidase involved with processing of glyceride-modified proteins 


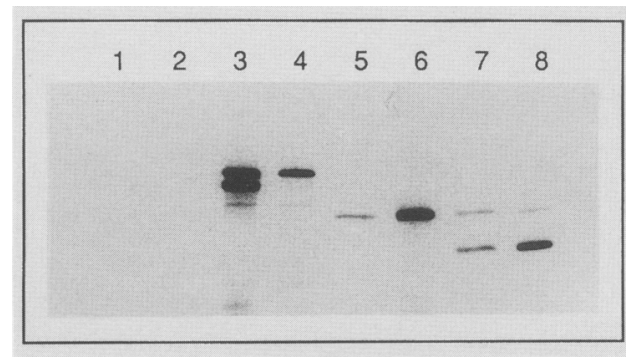

Figure 8. TcpA processing in a leader peptidase mutant. (Lane 1) Parent strain W3110 pGP1-2 pGEM-3Z; (lane 2) lep mutant IT41 pGP1-2 pGEM-3Z; (lane 3) W3110 pGP1-2 pDMS9 demonstrating wild-type processing of $\beta$-lactamase; (lane 4) IT41 pGP1-2 pDMS9 showing $\beta$-lactamase precursor accumulation at nonpermissive temperatures; (lane 5) W3110 pGP1-2 p3Z-A; (lane 6) IT41 pGP1-2 p3Z-A; (lane 7) W3110 pGP1-2 pRIN2A.7; (lane 8) IT41 pGP1-2 pRIN2A.7 shows that TcpA processing continues in the absence of a functional leader peptidase.

(Yamada et al. 1984) with globomycin treatment also did not alter TcpA processing. Thus, it appears that TcpI functions independently to specifically cleave the leader peptide from precursor TcpA. This is consistent with the recent demonstration of a peptidase function for $P$. aeruginosa PilD, suggesting the elucidation of a common class of proteases involved in the biogenesis of certain extracellular proteins.

Because the processing of these exported proteins appears to be independent of that found for proteins that follow the classical export pathway, it was of interest to determine whether TcpA export shares other features of the general secretion pathway. Jamming of general export by induction of a LamB-LacZ fusion protein resulted in accumulation of both $\beta$-lactamase and TcpA in their precursor forms. This result may indicate that either TcpA relies on portions of the classical machinery for leader peptide cleavage or that the effect we observe

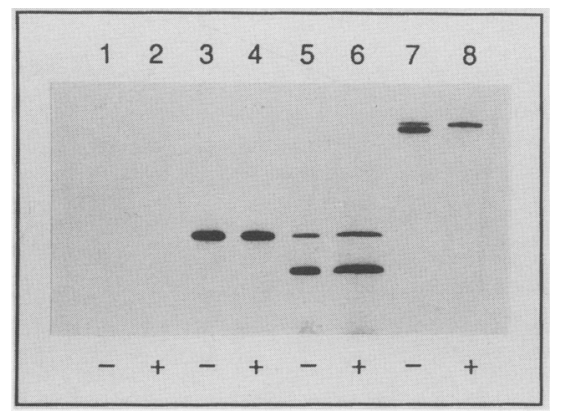

Figure 9. TcpA processing in the presence of globomycin. $1+1$ Lanes containing cultures incubated with globomycin $(40 \mu \mathrm{g} /$ $\mathrm{ml}$ ) for $20 \mathrm{~min}$ prior to labeling. (Lanes 1,2) K38 pGP1-2 pGEM3Z; (lanes 3,4) K38 pGP1-2 p3Z-A; (lanes 5,6) K38 pGP1-2 pRIN2A.7; showing that incubation with globomycin does not effect TcpA processing; (lanes 7,8) K38 pGP1-2 pC5 demonstrating the inhibition of lipoprotein $\mathrm{TcpC}$ leader peptide cleavage upon the addition of globomycin.

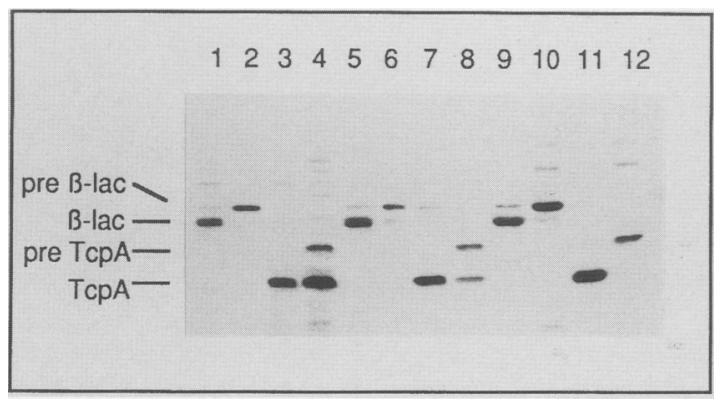

Figure 10. Inhibition of TcpA processing in induced LamBLacZ strain. Bacteria were grown in M9 glycerol to mid-log stage and induced with $0.2 \%$ maltose for either $1 \mathrm{hr}$ (lanes 1-4), $2 \mathrm{hr}$ (lanes 5-8, or $3 \mathrm{hr}$ (lanes 9-12) prior to rifampicin treatment and labeling. (Lanes 1,5,9) BZR60 pGP1-2 pDMS9; (lanes 2,6,10) DK2179 pGP1-2 pDMS9; (lanes 3,7,11) BZR60 pGP1-2 pRIN2A.7; (lanes 4, 8, 12) DK2179 pGP1-2 pRIN2A.7.

in indirect, that is, processing is inhibited as the result of improper localization or conformation of $\mathrm{TcpJ}$ in the compromised inner membrane. To define more accurately the step at which cleavage may be affected, we examined TcpA processing in an $E$. coli strain treated with a low concentration of sodium azide to specifically inhibit SecA function. In contrast to the membrane-jamming experiment, pilin cleavage was not altered by azide treatment. Thus, it seems that TcpA processing is independent of at least one major component of the classical export pathway, SecA, and that the defect seen under membrane-jamming conditions reflects dependence on another sec gene product or is sensitive to the general membrane state existing under these conditions.

Figure 12 serves to contrast the signal-processing event of proteins that utilize the classical pathway with those that are processed by the class of leader peptidases exemplified by TcpJ. In the case of general export, a complex including SecA, the signal sequence of the targeted protein and, in some cases, the SecB chaperone, interact with an integral membrane complex containing the SecY

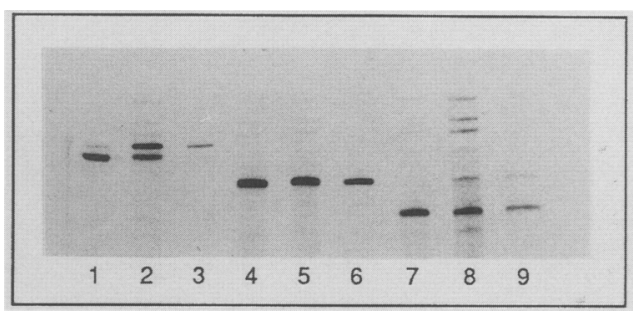

Figure 11. TcpA processing in the presence of sodium azide. Sodium azide at a final concentration of $2 \mathrm{~mm}$ was added to rifampicin-treated cultures for either $0 \mathrm{~min}$ (lanes 1,4,7), $3 \mathrm{~min}$ (lanes 2,5,8), or $12 \mathrm{~min}$ (lanes $3,6,9$ ) prior to labeling for $5 \mathrm{~min}$. Lanes 1-3 demonstrate the effect of azide on $\beta$-lactamase in strain BZR60 pGP1-2 pDMS9; lanes 4-6 show precursor TcpA in strain BZR60 pGP1-2 p3Z-A; lanes 7-9 contain BZR60 pGP1-2 pRIN2A.7. 


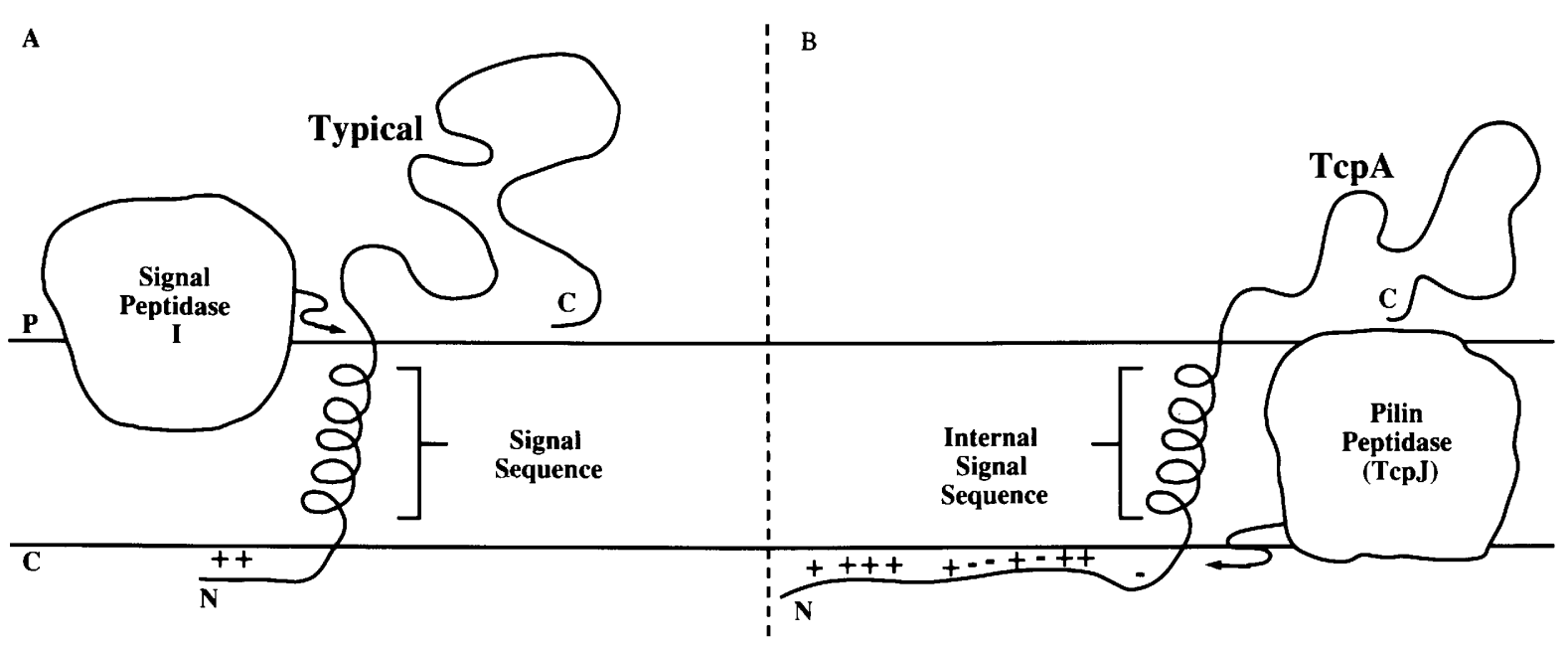

Figure 12. Comparison of TcpJ function with leader peptidase. $(A)$ During general export in $E$. coli, the amino terminal hydrophobic signal sequence of proteins to be translocated has a transmembrane orientation and is cleaved by signal peptidase I in the periplasm. $(B)$ For secretion of TcpA, the hydrophilic leader peptide is likely to interact with the inner membrane and be cleaved on the cytoplasmic face. The membrane-embedded signal sequence for export is located in the mature pilin molecule. Cleavage of the basic leader could then allow release of pilin from the membrane for surface assembly, which is likely mediated by the products of additional TCP biogenesis genes.

and SecE proteins (for recent review, see Schatz and Beckwith 1990). The signal sequence that promotes these events lies at the amino terminus of the precursor form of the secreted protein and is characterized by one or two basic residues followed by a hydrophobic core and a consensus proteolytic processing site (von Heijne 1986). Subsequent to the initiation of export through the integral membrane complex, cleavage of the signal sequence occurs on the periplasmic side of the cytoplasmic membrane. Work with type 4 pilins has demonstrated that the processed amino-terminal region is not itself sufficient for secretion but that the hydrophobic portion, which is retained by the mature protein, is also necessary (Strom and Lory 1987), thus functioning as an internal signal sequence for the precursor pilin. The cleaved amino-terminal portion of these pilins is positively charged and reminiscent of the first residue generally found on a typical leader sequence. Thus, in the case of type 4 pilin-like leaders, it may be a combination of this charged region and the hydrophobic domain that functions as a secretion signal. These molecules then associate with the membrane, and at least in the case of TcpA, in a SecA-independent fashion. The amino-terminal leader of the membrane-bound prepilin is then cleaved by a specific protease that differs from the classical pathway. This cleavage event is likely to occur on the cytoplasmic side of the membrane, on the basis of the deduced orientation of the protein, and its subsequent methylation at the amino position of the mature protein. This mechanism may impart in the protein the ability to remain in the membrane until released to the outside of the cell, perhaps through membrane junctions. The thinsection pilin localization experiments reveal that the nonpolymerized cell-associated pilin is always membrane-bound. This localization has also been docu- mented for $P$. aeruginosa type 4 pilin (Pasloske and Parancych 1988; Strom and Lory 1991).

It would appear that a common mechanism has evolved for both pilin secretion and some other types of extracellular export by gram-negative bacteria. Homology of the pilin leader region and its cleavage sites extends to proteins involved in extracellular secretion in other systems, such as pullulunase of $K$. pneumoniae, and for such cell-surface proteins required for transformation of B. subtilis (Strom and Lory 1991). As shown in Figure 4, we find that this homology extends through corresponding secretion molecules associated with each of these systems.

\section{Materials and methods}

\section{Bacterial strains and plasmids}

The following strains were used in this study: E. coli, SE5000 $\left[\mathrm{F}^{-}\right.$araD139 $\Delta(\arg F-$ lac) $)$ U169 rpsL150 relA1 flbB5301 deoCl ptsF25 rbsR recA56] (Silhavy et al. 1984); JM83 [ara $\Delta$ (lac-

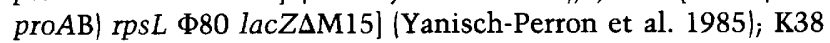
(HfrC $\lambda$ ) (Russel and Model 1984); IT41 (W3110 lep9 (am) Tet ${ }^{\mathrm{T}}$ ) (Inada et al. 1989); JF626 [ $\Delta($ lac-pro) thi rpsL supE endA sbcB15 hsdR4/F' traD36 proA ${ }^{+} B^{+}$lacl ${ }^{\mathrm{a}}$ lacZM15] (J. Felton); SM10

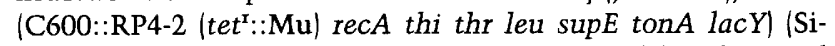
mon et al. 1983); MM294 (endA hsdR pro supF) (Ruvkun and

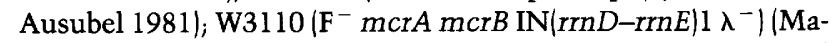
niatis et al. 1982); DK2179 (MC4100 lamB-lacZ\$ 42-1); and BZR60 (MC4100 $\operatorname{lamB} \Delta 60-1 a c Z \Phi$ 42-1) (Emr and Silhavy 1980). V. cholerae, O395 (classical, Ogawa $\operatorname{Str}^{\mathrm{r}}$ derivative), J71K-1 (O395 tcp/::kan ${ }^{\mathrm{r}}$ ). Laboratory clones: pDra9 (tcpA on 1.1-kb DraI fragment in vector pLG339; Stoker et al. 1982); p325-J ( $t c p$ I on 3.3-kb HindIII-EcoRV fragment in pBR325; Bolivar 1978); pCS19H (3.3-kb HindIII-EcoRV tcpI clone in pBR322; Shaw and Taylor 1990); and p3Z-J (3.3-kb HindIIIEcoRV tcpI clone in pGEM-3Z; Promega). For T7 analysis, plas- 
mid pGEM-3Z containing the T7 promoter adjacent to the multiple cloning site was used as the vector to carry $t c p A$ and $t c p J$. A 980-bp EcoRI-NsiI fragment containing tcp/ from p325-J was inserted into the EcoRI-PstI sites of pGEM-3Z, creating pRIN980. This construct was restricted with SmaI and ligated with a 1.1-kb DraI fragment containing tcpA from laboratory clone pRTG7H3 (Shaw and Taylor 1990) to create pRIN2A.7. An additional T7 expression plasmid containing only tcp $A$ was also constructed using the DraI-SmaI rationale (p3Z-A) to demonstrate the behavior of TcpA in E. coli in the absence of TcpJ. Plasmid pGP1-2 was used in T7 analyses as a source of thermoinducible T7 polymerase (Tabor and Richardson 1985). Plasmid pDMS9 expresses $\beta$-lactamase as three bands of $\sim 33,31$, and $29 \mathrm{kD}$ corresponding to the unprocessed precursor, the mature protein, and an additional translated segment (Schifferli et al. 1991).

\section{Media and chemicals}

E. coli strains were routinely grown in LB (Miller 1972), supplemented with appropriate antibiotics. For optimal expression of $\mathrm{TCP}, V$. cholerae strains were grown at $30^{\circ} \mathrm{C}$ in $\mathrm{LB}$ at $\mathrm{pH} 6.5$. Tryptone, yeast extract, Bacto-agar, and TCBS agar were purchased from Difco Laboratories. All restriction enzymes, modification enzymes, and T4 DNA ligase were purchased from New England Biolabs. Ampicillin, kanamycin, streptomycin, rifampicin, and gentamicin were purchased from Sigma Chemical Co. and used at the following concentrations: 100, 45, 100, 200 , and $30 \mu \mathrm{g} / \mathrm{ml}$, respectively. Globomycin was a generous gift from M. Arai (Sankyo Co., Tokyo) and was used at $40 \mu \mathrm{g} / \mathrm{ml}$. Isotopes for radiolabeling protein $\left[{ }^{35} \mathrm{~S}\right]$ methionine, or nucleic acid $\left[\alpha-{ }^{32}\right.$ P]dATP or $\left[\alpha^{-35}\right.$ S $]$-labeled dATP were from New England Nuclear.

\section{Nucleic acid manipulations}

All DNA manipulations were performed essentially as described in Maniatis et al. (1982). The dideoxy chain-termination method developed by Sanger et al. (1977) was employed with the use of Sequenase (U.S. Biochemical Corporation) to determine the nucleotide sequence of $t c p J$. The sequence analysis software package of the University of Wisconsin Genetics Computer Group was used to process and analyze nucleic acid and protein sequence data (Devereaux et al. 1984).

\section{Creation of tcpJ mutant $/ 71 \mathrm{~K}-1$}

A $3.5-\mathrm{kb}$ BglII fragment containing $t c p /$ with the kanamycinresistance cartridge insertion lesion was subcloned into the BamHI site of pLAFR2 (Friedman et al. 1982), a cosmid derivative of $\mathrm{Tc}^{\mathrm{r}}$ broad host range IncP1 replicon pRK290 (Ditta et al. 1980). The resulting construct, $\mathrm{pJ} 71 \mathrm{~K}$, was used to recombine the insertion mutation into $V$. cholerae strain 0395 with incompatible plasmids, as described previously (Ruvkun and Ausubel 1981; Taylor et al. 1989).

\section{Western blots}

Western blotting was performed as a modification of the protocol described by Towbin et al. (1979). Samples were solubilized by boiling in cracking buffer containing SDS and 2-mercaptoethanol prior to SDS-PAGE (Laemmli 1970). Separated proteins were electroblotted to nitrocellulose membranes (Schleicher \& Schuell) in Tris-glycine buffer. Membranes were submerged in blocking solution composed of $2 \%$ gelatin and $2 \%$ non-fat dried milk in Tris-buffered saline containing Tween 20 (TBS-Tween) for $20 \mathrm{~min}$. Following blocking, blots were incubated with primary antiserum diluted appropriately in blocking solution overnight at $37^{\circ} \mathrm{C}$. Membranes were washed extensively in TBSTween and probed with $1: 1500$ dilution of peroxidase-conjugated goat anti-rabbit IgG (Cappel) in blocking solution at room temperature for $30 \mathrm{~min}$. After additional washes with TBSTween, reactive proteins were identified by development with substrate/chromagen combination hydrogen peroxide/horseradish peroxidase color development reagent (Bio-Rad).

\section{Southern hybridization}

Restriction fragments used as hybridization probes were purified from agarose by Geneclean (Biol01) and radiolabeled with the Random Primer DNA labeling kit of Boehringer Mannheim.

\section{$T 7$ expression system and pulse-chase analysis}

$\mathrm{T} 7$ analysis was conducted as outlined by Tabor and Richardson (1985). Appropriate strains were grown at $30^{\circ} \mathrm{C}$ in selective media to mid-log stage, harvested by centrifugation, washed, and resuspended in a defined medium containing all common amino acids except methionine and cysteine. Following a $60-$ min outgrowth at $30^{\circ} \mathrm{C}$, cultures were shifted to $42^{\circ} \mathrm{C}$ to induce production of $\mathrm{T} 7$ polymerase. Rifampicin was added $15 \mathrm{~min}$ postinduction. Cells continued to incubate for $10 \mathrm{~min}$ at $42^{\circ} \mathrm{C}$ and were shifted to $30^{\circ} \mathrm{C}$ for $20 \mathrm{~min}$ prior to pulsing with $\left[{ }^{35} \mathrm{~S}\right]$ methionine. For routine $\mathrm{T} 7$ analysis, cells were centrifuged and lysed in cracking buffer after a 5-min incubation with radiolabeled amino acid. For pulse-chase analysis, incorporation of label for $2 \mathrm{~min}$ was terminated by the addition of excess cold methionine. Aliquots were removed at $0,1,5,15,30$, and 60 min and plunged into a dry ice/ethanol bath to halt cell growth immediately. Proteins were solubilized by boiling in cracking buffer, and samples were electrophoresed on a SDS-polyacrylamide gel. Prior to autoradiography, the gel was stained with Coomassie brilliant blue (Bio-Rad), fixed in 5\% methanol $/ 5 \%$ acetic acid, treated with $1 \mathrm{~mm}$ sodium salicylate containing $10 \%$ glycerol, and dried (Chamberlin 1979).

\section{Amino acid sequencing of precursor TcpA}

Construct p3Z-A was used to overproduce $23-\mathrm{kD}$ prepilin in $E$. coli by a modified T7 assay. K38 pGP1-2 p3Z-A was grown in selective media at $30^{\circ} \mathrm{C}$ to mid-log phase and shifted to $42^{\circ} \mathrm{C}$ for $15 \mathrm{~min}$, and rifampicin was added. Incubation at $42^{\circ} \mathrm{C}$ was maintained for an additional hour to achieve maximum production of plasmid-encoded TcpA. Cells were pelleted, lysed in cracking buffer, and resolved by SDS-PAGE in the presence of thioglycolate. Proteins were electroblotted onto an Immobilon PVDF membrane (Millipore) in CAPS (10 mM 3-[cyclohexylamino]-1-propanesulfonic acid, $10 \%$ methanol (vol/vol) at $\mathrm{pH}$ 11.0) transfer buffer as described by Matsudaira (1987). Strips cut from outside edges of the membrane were probed with antiTcpA antisera to locate the band of interest. The remainder of the membrane was stained with Coomassie brilliant blue, and the $23-\mathrm{kD}$ TcpA band was excised. The 30 amino-terminal residues were microsequenced on an Applied Biosystems model 477A sequencer. Resulting phenylthiohydantoin derivatives were separated by reverse-phase high-performance liquid chromatography (HPLC) and identified against standards.

\section{Analysis of amino-terminal modification}

Partially purified pilin collected from cell-surface shearates of $V$. cholerae (Sun et al. 1990) was subjected to SDS-PAGE and blotted to Immobilon as outlined previously. The chromato- 
graphic behavior of the modified amino-terminal methionine residue was compared with a panel of commercially available methionine derivatives (Sigma): L-methionine sulfone, $S$-methylmethionine sulfonium chloride, cystathionine, and homocysteine. Additionally, the reductive alkylation technique of Means and Feeney (1968) was used to monomethylate the tripeptide L-methionyl-L-ananyl-L-serine (Sigma) for analysis. Phenylthiohydiantoin (PTH) derivatives of the methylated peptide, its unmethylated parent, the methionine derivatives, and the amino-terminal residue of TcpA were resolved by HPLC with a gradient of $0.1 \mathrm{M}$ sodium acetate $(\mathrm{pH} 3.8)$, as described by Stock et al. (1987).

\section{Lowicryl embedding and electron microscopy}

Lowicryl embedding of bacteria was performed as a modification of the protocol of Hobot et al. (1987). V. cholerae strains O395 and J71K-1 were grown under conditions optimal for TCP expression (LB, at $\mathrm{pH} 6.5$, and $30^{\circ} \mathrm{C}$ overnight), pelleted by centrifugation, and washed in PBS (pH 7.4). Bacteria were incubated in a solution of $0.5 \%$ gluteraldehyde in PBS for $30 \mathrm{~min}$, washed twice in PBS, and embedded in $2 \%$ agar (BBL purified agar). Dehydration of samples was carried out by suspending the agar blocks in progressively higher concentrations of ethanol $130 \%$, $50 \%, 70 \%, 95 \%$, absolute $)$ in a gradient of temperatures $(0,-20$, $-35^{\circ} \mathrm{C}$. Bacteria were infiltrated with hydrophilic methacrylate-embedding medium Lowicryl K11M (Polysciences) at $-35^{\circ} \mathrm{C}$. Photopolymerization of resin was accomplished by exposure to UV irradiation for 3 days at $-35^{\circ} \mathrm{C}$ followed by 3 -day exposure at room temperature. Hardened blocks were thin-sectioned on an Ultracut E microtome (Reichert-Jung) to a thickness of $60 \mathrm{~nm}$. Sections were collected on Formvar and carboncoated nickle grids, blocked with $0.5 \% \mathrm{BSA}$, and incubated with one of the following antisera: anti-TcpAl polyclonal at $1: 50$ (Sun et al. 1991), normal rabbit sera at $1: 200$, or anti-DNA monoclonal at $1: 50$ (kindly supplied by Tony Marion). After washing with PBS, grids were floated on a suspension of protein A-collodial gold (Auroprobe, $10 \mathrm{~nm}$, Amersham). Sections were washed extensively with $\mathrm{PBS}$ and $\mathrm{ddH}_{2} \mathrm{O}$, stained with saturated uranyl acetate, and exposed briefly to lead citrate. Negative staining of bacteria was accomplished by floating Formvarcoated copper grids on a drop of bacteria from an overnight culture followed by exposure to phosphotungstic acid $(\mathrm{pH} 6.5)$ for $1 \mathrm{~min}$. Immunolabeled and negatively stained organisms were viewed with a JEM 1200 EX transmission electron microscope operating at $60 \mathrm{kV}$. For immunolabeled sections, electron micrographs were evaluated for distribution of gold particles, and average values for each compartment and the extracellular space were calculated.

\section{Transformation of $\mathrm{V}$. cholerae}

The protocol for plasmid transformation of $V$. cholerae was kindly provided by Steven R. Johnson. Bacteria were grown for $14 \mathrm{hr}$ in brain heart infusion (BHI) media (Difco), diluted $1: 10$ in $15 \mathrm{ml}$ of BHI with $50 \mathrm{mM} \mathrm{MgSO}_{4}$, and incubated for $1 \mathrm{hr}$ at $37^{\circ} \mathrm{C}$. Following a $20-\mathrm{min}$ cooling on ice, bacteria were centrifuged and washed in $14 \mathrm{ml}$ of competence solution I (10 mM $\mathrm{NaCl}, 5 \mathrm{~mm} \mathrm{KCl}$, and $50 \mathrm{~mm} \mathrm{MgCl}_{2}$ ) at $0^{\circ} \mathrm{C}$. Cells were centrifuged again, resuspended in $14 \mathrm{ml}$ of competence solution II $100 \mathrm{mM} \mathrm{CaCl}_{2}, 100 \mathrm{~mm} \mathrm{KCl}, 10 \mathrm{mM} \mathrm{MnCl}$, and $10 \mathrm{~mm}$ ACES at $\mathrm{pH} \mathrm{6.7)} \mathrm{and} \mathrm{incubated} \mathrm{on} \mathrm{ice} \mathrm{for} 20 \mathrm{~min}$. Bacteria were pelleted, resuspended in $4 \mathrm{ml}$ of competence solution II, with the addition of $0.4 \mathrm{ml}$ of $50 \%$ PEG-8000, and held on ice overnight. Cells $(250-300 \mu \mathrm{l})$ were incubated with $10 \mu \mathrm{l}$ of miniprep DNA on ice for $1 \mathrm{hr}$. Cells were heat-shocked for $1.5 \mathrm{~min}$ at $37^{\circ} \mathrm{C}, 1 \mathrm{ml}$ of $\mathrm{BHI}$ was added, and $4 \mathrm{hr}$ of outgrowth at $37^{\circ} \mathrm{C}$ was allowed prior to plating on selective media.

\section{Acknowledgments}

We thank C. Shaw for the initial plasmids carrying tcpA and $t c p /$. We also thank L. Hatmaker for excellent technical assistance in electron microscopy, P. Ryan, T. Silhavy, and A. Stock for insightful discussions, $S$. Lory for conveying results prior to publication, T. Marion for anti-DNA monoclonal antisera, $M$. Arai for globomycin, S. Johnson for the $V$. cholerae transformation protocol, and C. Brown, M. Howe, Y. Nakamura, D. Schifferli, and T. Silhavy for plasmids and strains. This work was supported by National Institutes of Health (NIH) grant AI-25096 to R.K.T. M.R.K. is the recipient of NIH predoctoral training grant AI-07238.

The publication costs of this article were defrayed in part by payment of page charges. This article must therefore be hereby marked "advertisement" in accordance with 18 USC section 1734 solely to indicate this fact.

\section{References}

Bayer, M.E., M.H. Bayer, C.A. Lunn, and V. Pigiet. 1987. Association of thioredoxin with the inner membrane and adhesion sites in Escherichia coli. J. Bacteriol. 169: 2659-2666.

Berg, J. M. 1990. Zinc finger domains: Hypotheses and current knowledge. Annu. Rev. Biophys. Biophys. Chem. 19: 405421.

Bieker, K.L. and T.J. Silhavy. 1989. PrlA is important for the translocation of exported proteins across the cytoplasmic membrane of Escherichia coli. Proc. Natl. Acad. Sci. 86: 968-972.

Bieker, K.L., G.J. Phillips, and T. Silhavy. 1990. The sec and prl genes of Escherichia coli. I. Bioenerg. Biomembr. 22: 291310 .

Bimboim, H.C. 1983. A rapid alkaline extraction method for the isolation of plasmid DNA. Methods Enzymol. 100: 243-255.

Bolivar, F. 1978. Construction and characterization of new cloning vehicles, III. Derivatives of plasmid pBR322 carrying unique EcoRI sites for selection of EcoRI generated recombinant molecules. Gene 4: 121-136.

Cabelli, R. J., L. Chen, P.C. Tai, and D.B. Oliver. 1988. SecA protein is required for secretory protein translocation into $E$. coli membrane vesicles. Cell 55: 683-692.

Chamberlin, J.P. 1979. Fluorographic detection of radioactivity in polyacrylamide gels with the water soluble fluor, sodium salicylate. Anal. Biochem. 98: 132-135.

Devereaux, J., P. Haeberli, and O. Smithies. 1984. A comprehensive set of sequence analysis programs for the VAX. $\mathrm{Nu}$ cleic Acids Res. 12: 387-395.

Ditta, G., S. Stanfield, D. Corbin, and D.R. Helinski. 1980. Broad host range DNA cloning system for gram-negative bacteria: Construction of a gene bank of Rhizobium meililoti. Proc. Natl. Acad. Sci. 77: 7347-7351.

Durrenberger, M., M. Bjornsti, T. Uetz, J.A. Hobot, and E. Kellenberger. 1988. Intracellular location of the histonelike protein HU in Escherichia coli. J. Bacteriol. 170: 4757-4768.

Emr, S.D. and T.J. Silhavy. 1980. Mutations affecting localization of an Escherichia coli outer membrane protein, the bacteriophage lambda receptor. I. Mol. Biol. 141: 63-90.

Faast, R., M.A. Ogierman, U.H. Stroeher, and P.A. Manning. 1989. Nucleotide sequence of the structural gene, tcpA, for a major pilin subunit of Vibrio cholerae. Gene 85: 227-231. 
Friedman, A.M., S. Long, S. Brown, W. Buikema, and F. Ausubel. 1982. Construction of a broad host range cosmid cloning vector and its use in the genetic analysis of Rhizobium mutants. Gene 18: 289-296.

Hobot, J.A., M. Bjornsti, and E. Kellenberger. 1987. Use of onsection immunolabeling and cryosubstitution for studies of bacterial DNA distribution. J. Bacteriol. 169: 2055-2062.

Hussain, M., S. Ichihara, and S. Mizushima. 1980. Accumulation of glyceride-containing precursor of the outer membrane lipoprotein in the cytoplasmic membrane of Escherichia coli treated with globomycin. I. Biol. Chem. 255: 3707-3712.

Inada, T., D. Court, K. Ito, and Y. Nakamura. 1989. Conditionally lethal amber mutations in the leader peptidase gene of Escherichia coli. J. Bacteriol. 171: 585-587.

Kieny, M.P., R. Lathe, and J.P. Lecocq. 1983. New versatile cloning and sequencing vectors based on bacteriophage M13. Gene 26: 91-99.

Kyte, J. and R.F. Doolittle. 1982. A simple method for displaying the hydropathic character of a protein. I. Mol. Biol. 157: 105132.

Laemmli, U.K. 1970. Cleavage of structural proteins during the assembly of the head of bacteriophage T4. Nature 227: 680685.

Lill, R., K. Cunningham, L.A. Brundage, K. Ito, D. Oliver, and W. Wickner. 1989. SecA protein hydrolyzes ATP and is an essential component of the protein translocation ATPase of Escherichia coli. EMBO 1. 8: 961-966.

Lippman, D.J. and W.R. Pearson. 1985. Rapid and sensitive protein similarity searches. Science 227: 1435-1441.

Maniatis, T., E.F. Fritsch, and J. Sambrook. 1982. Molecular cloning: A laboratory manual. Cold Spring Harbor Laboratory. Cold Spring Harbor, New York.

Marion, T.N., A.R. Lawton III, J.F. Kearney, and D.E. Briles. 1982. Anti-DNA autoantibodies in $(\mathrm{NZB} \times \mathrm{NZW}) \mathrm{F}_{1}$ mice are clonally heterogeneous, but the majority share a common idiotype. J. Immunol. 128: 668-674.

Matsudaira, P. 1987. Sequence from picomole quantities of proteins electroblotted onto polyvinylidene difluoride membranes. J. Biol. Chem. 262: 10035-10038.

Means, G.E. and R.E. Feeney. 1968. Reductive alkylation of amino groups in proteins. Biochemistry 7: 2192-2201.

Messing, J. 1983. New M13 vectors for cloning. Methods Enzymol. 101: 20-89.

Miller, J.H. 1972. Experiments in molecular genetics. Cold Spring Harbor Laboratory. Cold Spring Harbor, New York.

Mohan, S., J. Aghion, N. Guillen, and D. Dubnau. 1989. Molecular cloning and characterization of $\operatorname{com} C$, a late competence gene of Bacillus subtilis. J. Bacteriol. 171: 6043-6051.

Nunn, D.N. and S. Lory. 1991. Product of the Pseudomonas aeruginosa gene pilD is a prepilin leader peptidase. Proc. Natl. Acad. Sci. 88: 3281-3285.

Nunn, D., S. Bergman, and S. Lory. 1990. Products of three accessory genes, pilB, pilC, and pilD, are required for biogenesis of Pseudomonas aeruginosa pili. I. Bacteriol. 172: 2911-2919.

Oliver, D.B. and J. Beckwith. 1982. Regulation of a membrane component required for protein secretion in Escherichia coli. Cell 30: 311-319.

Parsot, C., E. Taxman, and J.J. Mekalanos. 1991. ToxR regulates the production of lipoproteins and the expression of serum resistance in Vibrio cholerae. Proc. Natl. Acad. Sci. 88: $1641-1645$.

Pasloske, B.L. and W. Parancych. 1988. The expression of mutant pilins in Pseudomonas aeruginosa: Fifth position glutamate affects pilin methylation. Mol. Microbiol. 2: 489-495.
Pugsley, A.P. and I. Reyss. 1990. Five genes at the $3^{\prime}$ end of the Klebsiella pneumoniae pulC operon are required for pullulanase secretion. Mol. Microbiol. 4: 365-379.

Russel, M. and P. Model. 1984. Replacement of the fip gene of Escherichia coli by an inactive gene cloned on a plasmid. I. Bacteriol. 159: 1035-1039.

Ruther, U. 1980. Construction and properties of a new cloning vehicle, allowing direct sequencing for recombinant plasmids. Mol. Gen. Genet. 178: 475-477.

Ruvkun, G.B. and F. M. Ausubel. 1981. A general method for site-directed mutagenesis in prokaryotes. Nature 289: 8588.

Sanger, F., S. Nicklen, and A. R. Coulson. 1977. DNA sequencing with chain-terminating inhibitors. Proc. Natl. Acad. Sci. 74: 5463-5467.

Schatz, P. and J. Beckwith. 1990. Genetic analysis of protein export in Escherichia coli. Annu. Rev. Genet. 24: 215-248.

Schifferli, D.S., E.H. Beachey, and R.K. Taylor. 1991. 987P fimbrial gene identification and protein characterization by $\mathrm{T} 7$ RNA polymerase-induced transcription and TnphoA mutagenesis. Mol. Microbiol. 5: 61-70.

Senior, A.E. 1990. The proton-translocating ATPase of Escherichia coli. Annu. Rev. Biophys. Biophys. Chem. 19: 7-41.

Shaw, C.E. 1988. M.S. thesis, "Genetic characterization of a V-cholerae colonization locus." University of Tennessee, Memphis, TN.

Shaw, C.E. and R.K. Taylor. 1990. Vibrio cholerae O395 tcpA pilin gene sequence and comparison of predicted protein structural features to those of Type 4 pilins. Infect. Immun. 58: 3042-3049.

Shine, J. and L. Dalgarno. 1974. The 3 '-terminal sequence of Escherichia coli $16 \mathrm{~S}$ ribosomal RNA: Complementarity to nonsense triplets and ribosome binding sites. Proc. Natl. Acad. Sci. 71: 1342-1346.

Silhavy, T.J., M.L. Berman, and L.W. Enquist. 1984. Experiments with gene fusions. Cold Spring Harbor Laboratory. Cold Spring Harbor, New York.

Simon, R., U. Priefer, and A. Puhler. 1983. A broad host range mobilization system for in vivo genetic engineering: Transposon mutagenesis in gram negative bacteria. Biotechnology 1: 784-791.

Southern, E.M. 1975. Detection of sequences among DNA fragments separated by gel electrophoresis. J. Mol. Biol. 98: 503517.

Stock, A., E. Schaeffer, D.E. Koshland Jr., and J. Stock. 1987. A second type of protein methylation reaction in bacterial chemotaxis. J. Biol. Chem. 26: 8011-8014.

Stoker, N.G., N.F. Fairweather, and B.G. Spratt. 1982. Versatile low-copy-number plasmid vectors for cloning in Escherichia coli. Gene 18: 335-341.

Strom, M.S. and S. Lory. 1987. Mapping of export signals of Pseudomonas aeruginosa pilin with alkaline phosphatase fusions. J. Bacteriol. 169: 3181-3188.

1991. Amino acid substitutions in pilin of Pseudomonas aeruginosa: Effect on leader peptide cleavage, amino-terminal methylation, and pilus assembly, J. Biol. Chem. 266: 1656-1664.

Sun, D., J.J. Mekalanos, and R.K. Taylor. 1990. Antibodies directed against the toxin-coregulated pilus isolated from Vibrio cholerae provide protection in the infant mouse experimental cholera model. I. Infect. Dis. 161: 1231-1236.

Sun, D., J.M. Seyer, I. Kovari, R.A. Sumrada, and R.K. Taylor. 1991. Localization of protective epitopes within the pilin subunit of the Vibrio cholerae toxin-coregulated pilus. Infect. Immun. 59: 114-118.

Tabor, S. and C.C. Richardson. 1985. A bacteriophage T7 RNA 
polymerase/promoter system for controlled exclusive expression of specific genes. Proc. Natl. Acad. Sci. 82: 10741078.

Taylor, R.K., V.L. Miller, D.B. Furlong, and J.J. Mekalanos. 1987. Use of phoA gene fusions to identify a pilus colonization factor coordinately regulated with cholera toxin. Proc. Natl. Acad. Sci. 84: 2833-2837.

Taylor, R.K., C. Shaw, K. Peterson, P. Spears, and J. Mekalanos. 1988. Safe, live Vibrio cholerae vaccines? Vaccine 6: 151154.

Taylor, R.K., C. Manoil, and J.J. Mekalanos. 1989. Broad-host range vectors for delivery of $\operatorname{Tn} p h o A$ : Use in genetic analysis of secreted virulence determinants of Vibrio cholerae. J. Bacteriol. 171: 1870-1878.

Tennent, J.M., S. Hultgren, B. Marklund, K. Forsman, M. Goransson, B.E. Uhlin, and S. Normark. 1990. Genetics of adhesion expression in Escherichia coli. In The bacteria. (ed. B. Iglewski and V. Clark), Vol. XI. Academic Press, San Diego.

Towbin, H., T. Staehelin, and J. Gordon. 1979. Electrophoretic transfer of proteins from polyacrylamide gels to nitrocellulose sheets: Procedure and some applications. Proc. Natl. Acad. Sci. 78: 4350-4354.

von Heijne, G. 1986. A new method for predicting signal sequence cleavage sites. Nucleic Acids Res. 14: 4683-4690.

Yamada, H., H. Yamagata, and S. Mizushima. 1984. The major outer membrane lipoprotein and new lipoproteins share a common signal peptidase that exists in the cytoplasmic membrane of Escherichia coli. FEBS Lett. 166: 179-182.

Yanisch-Perron, C., J. Vieira, and J. Messing. 1985. Improved M13 phage cloning vectors and host strains: Nucleotide sequences of the M13mpl 8 and $\mathrm{pUCl} 9$ vectors. Gene 33: 103 119. 


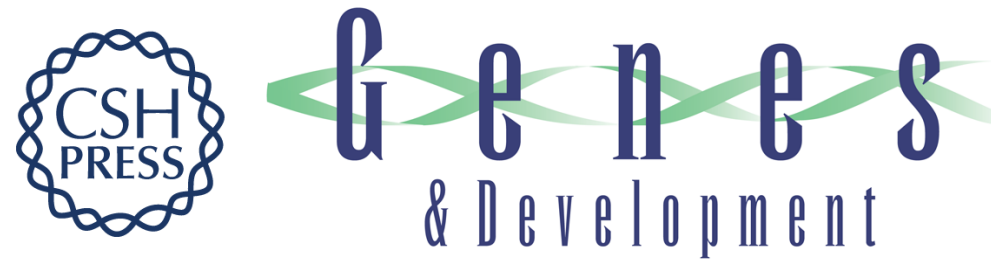

\section{Processing of TCP pilin by TcpJ typifies a common step intrinsic to a newly recognized pathway of extracellular protein secretion by gram-negative bacteria.}

M R Kaufman, J M Seyer and R K Taylor

Genes Dev. 1991, 5:

Access the most recent version at doi:10.1101/gad.5.10.1834

References This article cites 58 articles, 22 of which can be accessed free at:

http://genesdev.cshlp.org/content/5/10/1834.full.html\#ref-list-1

License

Email Alerting

Service

Receive free email alerts when new articles cite this article - sign up in the box at the top right corner of the article or click here.

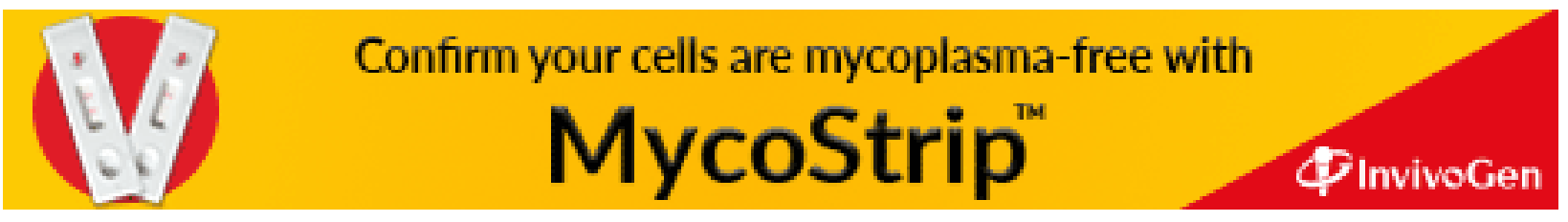

